Article

\title{
Field Recognition and the State Prerogative: Why Democratic Legitimation Recedes in Private Transnational Sustainability Regulation
}

\author{
Klaus Dingwerth \\ School of Economics and Political Science, University of St. Gallen, 9000 St. Gallen, Switzerland; \\ E-Mail: klaus.dingwerth@unisg.ch
}

Submitted: 4 October 2016 | Accepted: 25 October 2016 | Published: 15 March 2017

\begin{abstract}
Like any regulatory effort, private transnational standard-setters need to legitimate themselves to the audiences from which they seek support or obedience. While early scholarship on private transnational governance has emphasized the centrality of democratic legitimation narratives in rendering private governance socially acceptable, evidence from more recent standard-setting schemes suggests a declining relevance of that narrative over time. In my analysis of private sustainability regulation, I identify a combination of two factors that jointly contribute to this diminished role of democratic legitimation. First, private transnational governance has become a pervasive phenomenon. This means that new entrants to the field no longer face the same liability of newness that required first movers to make an extra effort in legitimation. Second, private standard-setting has moved from areas characterized by 'governance gaps' to areas in which meaningful intergovernmental regulation already exists. In these areas, however, the 'state prerogative' in legitimating governance holds. As a result, transnational standard-setters rely not so much on stressing their democratic credentials, but instead emphasize their contribution to achieving internationally agreed goals.
\end{abstract}

\section{Keywords}

democracy; global governance; legitimacy; private regulation; sustainability standards

\section{Issue}

This article is part of the issue "Legitimization of Private and Public Regulation: Past and Present", edited by Klaus Dieter Wolf (Peace Research Institute Frankfurt, Germany), Peter Collin (Max Planck Institute for European Legal History, Germany) and Melanie Coni-Zimmer (Peace Research Institute Frankfurt, Germany).

(C) 2017 by the author; licensee Cogitatio (Lisbon, Portugal). This article is licensed under a Creative Commons Attribution 4.0 International License (CC BY).

\section{Introduction}

In the 1990s, private transnational regulation was the proverbial new kid on the block. Observers saw world politics at a 'bifurcation', as the state-centric world of world politics was increasingly complemented, if not replaced, by a 'multi-centric' world of world politics in which private actors carved out spheres of authority for often very specific issues (Biersteker \& Hall, 2002; Cutler, Haufler, \& Porter, 1999; Haufler, 1993; Rosenau, 1990, 1995; Wapner, 1995).

In the field of sustainability governance, the proliferation of private transnational governance was particularly pronounced. While the CERES Principles set a code for the environmental conduct of companies, the Global Reporting Initiative (GRI) developed criteria geared to harmonize corporate reporting on environmental performance. Elsewhere, the Forest Stewardship Council (FSC) set standards for sustainable management of forests-an approach which the Marine Stewardship Council (MSC) soon copied for fisheries-and the World Commission on Dams (WCD) developed social and environmental guidelines for the international financing of large dams (Auld, 2014; Cashore, Auld, \& Newsom, 2004; Dingwerth, 2007; Gulbrandsen, 2010; Pattberg, 2007). Beyond the sustainability field, Fairtrade Labelling Organizations International and Utz Certified established fair trade standards while a wealth of initiatives developed and promoted fair labour standards for the textiles industry. Finally, in the new field of Internet governance, 
a private organization like the Internet Corporation for Assigned Names and Numbers became a key regulator; and even in international security, private companies offering security and military services had come to engage in meaningful self-regulation across borders (Krahmann, 2017).

Taken together, these developments suggested that private transnational regulation had moved significantly beyond its traditional confines of the transnational merchant rules-the lex mercatoria-and global sports governance-the lex sportiva (Wolf, 2017)-to become a key part of 'global governance' (Dingwerth \& Pattberg, 2006; Rosenau, 1995; Whitman, 2009). But how had it been possible for private regulators to gain-and subsequently maintain - the legitimacy they required to 'govern through markets' (Cashore et al., 2004)? Early scholarship had argued that, in the absence of a formal mandate to regulate 'for the rest of us' (Lipschutz \& Fogel, 2002), private regulators primarily relied on a democratic narrative (Bernstein \& Cashore, 2007; Dingwerth, 2007). Regulators argued that, in developing new regulation, all relevant stakeholders had been included in transparent and open decision-making processes.

In this article, I argue that the democratic narrative has lost some of its centrality in the legitimation of transnational governance over time. I define legitimation as a discursive practice in which actors exchange arguments to justify their support of, or challenge to, an institution or its activities. Democratic legitimation then constitutes the justification or critique of institutions based on values that are commonly associated with the democratic process. Based on my own previous work (Dingwerth, 2007, pp. 12-36), I take the latter to include the values of inclusiveness, participation, representation and responsiveness (participatory dimension); transparency and accountability (democratic control dimension); as well as the values of sincere deliberation and discursive openness (deliberative dimension). Taken together, the observation that democratic legitimation has declined in relevance in private transnational self-regulation stands in marked contrast to the rise of democratic norms in intergovernmental governance (Grigorescu, 2015). To account for the relative decline of the democratic legitimation narrative, I focus on two contributing factors.

First, a closer look at the legitimation of transnational governance reveals that the choice of legitimation strategies is closely linked to the presence or absence of state regulation. In fields characterized by 'governance gaps', private regulators strongly rely on democratic legitimation narratives. Where intergovernmental regulation exists, private regulators primarily seek to show how their work contributes to the goals set by public regulation. As a result, democratic legitimation is less central.

Second, even in fields with low levels of intergovernmental regulation, late entrants to the field face lower legitimation pressures than the first private regulators in the 1990s. Given the 'liability of newness' (Hannan \&
Freeman, 1984), the latter had to make an extra effort to legitimate themselves, and they largely answered this need by stressing their democratic credentials. Once private regulation had become more widely recognized as a legitimate field of global governance and once its role within the broader landscape of global governance largely was taken for granted, legitimation pressures weakened and democratic legitimation became less central.

\section{Legitimating Transnational Regulation}

In the following, I reconstruct the legitimation of private rule-making in the field of global sustainability governance in three steps. I distinguish between an early phase in which private regulation was a relatively novel phenomenon ('Emergence'), a second stage in which it had become widely recognized as an increasingly 'normal' element of global sustainability governance ('Evolution'), and a third phase in which it reached out to neighbouring issue areas ('Expansion'). Democratic legitimation frames, I argue, have played a major role in the first phase, but not necessarily in the second and third.

\subsection{Emergence}

In global sustainability governance, transnational standard systems have initially emerged in the 1970s, diversified in the 1990s and spread ever since then (Green, 2014, pp. 78-103). They now cover a variety of resources as well as cross-cutting issues such as environmental reporting, environmental management systems or social accountability. The FSC thus defines what counts as sustainable wood, the MSC provides the same service for wild-catch fish, Bonsucro for sustainable sugarcane, and the Roundtable for Sustainable Palm Oil (RSPO), the Roundtable for Responsible Soy (RTRS) and many others for additional renewable and non-renewable resources. Add a number of standards on greenhouse gas accounting, offsetting and management, on fair trade, on mining or on corporate conduct in the textiles industry and you will still only get a very rough idea about the breadth, depth and diversity in contemporary transnational regulation.

So what role do democratic norms play in the legitimation of transnational standard schemes in this issue area? The short answer is that they constitute one important legitimation resource along with the rule of law, continued progress and a contribution to problem-solving. The long answer is more complex. It points to different roles democratic norms and values play in relation to the distinct tasks of gaining and maintaining the legitimacy of transnational organizations, to the institutional embedding of transnational regulation in intergovernmental regimes, and to the influence the legitimation cultures prevailing in different policy fields may exert on the strength of democratic values.

Let us look at the short answer first. Here, the notion that a contribution to problem-solving-or effective- 
ness-is a necessary ingredient for successful claims to legitimacy is straightforward. At least in the environmental sustainability field, many transnational governance schemes thus emerged in the 1990s and 2000s on issues which governments had either sought but failed to regulate or not even sought to regulate in the first place. Set against this background, the fact that a transnational governance organization achieved at least something could be seen-and sold-as a success. The argument is thus one of responding to 'governance gaps'. Its common form would be that, if more and more companies procured wood or wood products and wild catch fish from sources certified as sustainable by the FSC and MSC, some trees and some fish stocks will be saved and some harm will therefore be prevented in comparison to a counterfactual world in which the FSC or MSC did not exist. Similarly, if the GRI manages to lure firms into regularly disclosing information about their environmental and human rights footprints, pressures to minimize such footprints are assumed to mount in the future, whether through consumer demands or investors' choices; and if decisions about large dams follow the guidelines developed by the WCD and include, for instance, sound impact assessments as well as the prior informed consent of indigenous groups affected by a project, we can continue to promote hydropower without repeating the mistakes made in the past.

Yet if effectiveness were the exclusive source of legitimation, most transnational governance schemes would stand on shaky ground. On the one hand, their actual contribution to problem-solving may either be unknown ormore likely-remain fairly modest. It may thus be true that the FSC or the GRI embody 'good ideas'. But if the FSC cannot help to significantly slow-down or even halt deforestation and if the GRI cannot help to make businesses truly environment-friendly and socially responsible, the organizations become open to a 'fig-leaf' critique according to which the commitment to transnational governance schemes simply allows firms or entire industries to 'greenwash' while continuing business as usual. As a result, continued progress becomes an important legitimation resource; it shows up in the growth rates which transnational schemes routinely stress in their annual reports, but also in concerns that further progress may be difficult to achieve once the 'low-hanging fruit' has been harvested. As the umbrella organization of the sustainability standards movement, the ISEAL Alliance, for instance, organized its 2012 Annual Conference under the label 'Beyond the 10 Percent', pointing to what many of its member organizations at the time perceived as a ceiling for their world market shares.

On the other hand, even if their effectiveness remains low, transnational governance schemes constitute regulatory interventions in markets. They publicly recognize and reward-sometimes in the form of a label, sometimes in other forms - the efforts of some market actors, but not of others. As they create value in this way, legal certainty becomes another relevant legitimation re- source: firms that are not rewarded must be able to know why and firms that are awarded must be shown to be in compliance with the rules laid down by a transnational governance scheme. The effect of this demand is an institutionalization and a legalization of transnational governance schemes which encompasses decision-making as well as implementation. The former includes the legislative function of establishing or amending the principles and criteria according to which the scheme distinguishes between those who are rewarded and those who are not, and the constitutional function of establishing or amending the rules of procedure for the governance scheme as a whole. What usually results then, are more or less full-fledged 'private regimes' (Haufler, 1993) that are, in important ways, modelled on the form and function of intergovernmental regimes.

Finally, the legislative function which transnational governance schemes adopt by devising 'rules for the world' raises the question who has mandated them to do so. This, in turn, makes references to democratic norms and values a fourth pillar of legitimacy claims. In short, those representing the schemes thus tend to argue that their organizations are designed so as to maximize the inclusion of affected 'stakeholder groups', the transparency of the decision-making process and the possibility for mutual learning in deliberative forums. To lend credibility to such claims, many organizations formally or informally divide seats in executive boards along the lines of pre-defined stakeholder groups, establish consultative stakeholder forums and allow for public comments periods when proposing new or amending existing regulations (Bernstein \& Cashore, 2007; Brassett, Richardson, \& Smith, 2012; Dingwerth, 2007; Dingwerth \& Pattberg, 2009).

Yet the reasons for adding this fourth pillar may be less obvious than for the first three legitimacy claims and hence require some further elaboration. Should a 'governance gap'-either alone or in combination with evidence for continued progress in addressing it and legal certainty for those who comply with a standard-not be a sufficiently powerful source of legitimation that renders the need for democratic legitimation less urgent, if not altogether obsolete; and if it is not, where does the demand for democratic legitimation arise from? I argue that it emerges for two reasons. First, even where a 'governance gap' is successfully constructed, it often remains contested. Industrialized nations may have argued for an international forest agreement; but the nations on whose territories much of the world's remaining forests are located identify the issue as being firmly within the boundaries of their national sovereignty. As a result, they reject the argument that a 'governance gap' actually exists (van Dam, 2002). Second, even if all or most relevant players were to agree that an issue demands regulation across borders, it may be far from clear who ought to regulate; and since the eventual choice of a regulator is likely to benefit some while putting others at a disadvantage, it will normally be contested (Benvenisti \& Downs, 2007). 
In response to both objections-is there really a governance gap, and if so, why should we allow this specific organization to respond to it? - , a solid response to the question why a specific organization is selected as a regulator becomes a central legitimation challenge. This is even more important where private transnational regulators are self-mandated.

While listing the four pillars might suggest a fairly simple and coherent legitimation process in which the ability to credibly make and defend four distinct claims is all one needs to be able to regulate, a closer look-as usualreveals that the actual dynamics are a bit more complex.

As a first context, gaining and maintaining legitimacy are thus distinct tasks transnational governance organizations confront, and democratic norms tend to matter differently at each stage. The argument I presented above is thus primarily linked to the need to gain legitimacy. Organizations like the FSC or the WCD constituted civil society organizations (CSOs) of a new kind (Wapner, 1995). They neither advocated for new intergovernmental norms, nor did they monitor compliance with existing rules. Instead, they sought to create new rules, hence embodying what Jessica Green (2014) has termed 'entrepreneurial' rather than 'delegated authority'. Yet to the extent that they engaged in this functionthat they sought to 'regulate for the rest of us' (Lipschutz \& Fogel, 2002)-it seemed only fair to demand that they conform to democratic principles. In contrast, had they limited their operations to the more traditional CSO turf, the same demand would have been much less compelling. Meeting the 'traditional' standards for advocacy NGOs would have been sufficient in this case (van Rooy, 2004).

But since organizations like the FSC were of a new kind and since they described the need for their emergence as resulting from the failure of intergovernmental agreements to halt deforestation, they needed a basis on which to claim legitimacy. Copying standard features of international institutions was one part of the solution. The FSC thus defined membership rules and categories, designated the general assembly of members as the highest decision-making body and designed the Principles and Criteria on which certification in a way that resembled an international legal document. In addition, the democratic quality of the decision-making process featured prominently in statements that sought to justify the license to regulate which FSC members had arrogated to themselves.

In addition to strategy, identity was relevant, too. In the FSC case, founding members thus had a background as grassroots environmentalists, and many of them valued democratic norms not only as a strategic resource but also saw them as appropriate from a normative point of view. At the same time, organizations that emerged after the FSC faced strong incentives to follow the same path whether or not they shared the same persuasions. On the one hand, funding for new initiatives was easier to obtain if one could argue to build on the FSC model that was field-tested and widely seen as a success (Bartley, 2007). On the other hand, the WWF became a major partner in several initiatives, thereby facilitating isomorphism within an emerging organizational field.

Over time, as more and more standard-setters followed the FSC template, a standard model from which others could deviate only at their own risk evolved (Bernstein \& Cashore, 2007; Dingwerth \& Pattberg, 2009). With the establishment of the ISEAL Alliance as an umbrella organization of transnational standard-setters in 2002 and the Alliance's adoption of the Code of Good Practice for Setting Social and Environmental Standards in 2004, this standard model was eventually codified. As Table 1 shows, it included a number of criteria that are closely linked to democratic values. Besides their functional role and their perception as 'appropriate' by some of the initiatives themselves, the inclusion of these criteria was also promoted by international trade law where the World Trade Organization Agreement on Technical Barriers to Trade stipulated criteria which 'international standards' had to fulfil in order to be compatible with world trade law (Bernstein, 2011, p. 38).

The adoption of the Code of Good Practice for Setting Social and Environmental Standards in 2004 signals the maturation of the organizational field. At the same time, it also marks an important change in the function democratic legitimation came to play as the field matured. While democratic legitimation had initially served to establish legitimacy for a new type of organization as such, its function now shifted to distinction, notably between the more and the less 'credible' actors in the field. The organizations that originally made up the field thus used the Code of Good Practice no longer to claim that transnational standard systems could be legitimate-that claim had been widely accepted in the meantime-but rather to draw a boundary between their own standard systems and competing initiatives which, they argued, did not (yet) deserve the same level of 'credibility'.

As the ISEAL Alliance expanded from the eight members which made up its ranks for most of the early years to twenty-two full members, it further expanded its instruments of distinction. Notably, it added an Impacts Code (in 2010) and an Assurance Code (in 2012) with which all members need to comply. The former requires members to systematically monitor and evaluate the short-term and long-term impacts of their standard systems. The latter formulates minimum requirements in areas such as rigor, consistency, competence, impartiality or transparency that member organizations need to meet in assuring compliance with social and environmental standards. Expanding the range of codes thus implies an extension of the list of legitimacy requirements to which ISEAL members are subjected. But at the same time, it also means that democratic decision-making is no longer an exclusive basis for legitimacy. Instead, it has become one among several normative frames that constitute the 'gold standard' of legitimate private regulation as formulated by the ISEAL Alliance. 
Table 1. References to democratic decision-making norms in the ISEAL Code. Source: ISEAL (2014).

\begin{tabular}{|c|c|c|}
\hline Clause & Requirement (or aspirational good practice) & Democratic value \\
\hline 4.1 & $\begin{array}{l}\text { Documented procedures for the process under which each standard is } \\
\text { developed or revised shall: a) form the basis of the standard-setting process; and } \\
\text { b) shall be made available to stakeholders, at a minimum through the } \\
\text { organization's website. }\end{array}$ & $\begin{array}{l}\text { Transparency } \\
\text { Accountability }\end{array}$ \\
\hline 5.2 .1 & $\begin{array}{l}\text { At the outset of a standards development or revision process, the } \\
\text { standard-setting organisation shall develop or update lists of sectors that have an } \\
\text { interest in the standard and key stakeholder groups within those sectors, based } \\
\text { on the standard's scope and its social, environmental and economic outcomes. }\end{array}$ & Inclusiveness \\
\hline 5.2 .2 & $\begin{array}{l}\text { The standard-setting organisation shall: a) seek to achieve representative } \\
\text { participation in its standard-setting activities. (aspirational good practice) }\end{array}$ & $\begin{array}{l}\text { Representation } \\
\text { Participation }\end{array}$ \\
\hline 5.4 .1 & $\begin{array}{l}\text { The public consultation phase for standards development or revision shall } \\
\text { include at least one round of } 60 \text { days for comment submissions by } \\
\text { stakeholders....For new standards development, a second round of consultation } \\
\text { of at least } 30 \text { days shall be included. }\end{array}$ & $\begin{array}{l}\text { Inclusiveness } \\
\text { Transparency }\end{array}$ \\
\hline 5.4 .2 & $\begin{array}{l}\text { The standard-setting organization shall ensure that participation in the } \\
\text { consultation process: a) is open to all stakeholders; and b) aims to achieve a } \\
\text { balance of interests in the subject matter and in the geographic scope to which } \\
\text { the standard applies. }\end{array}$ & Inclusiveness \\
\hline 5.4 .3 & $\begin{array}{l}\text { The standard-setting organisation shall provide stakeholders with appropriate } \\
\text { opportunities to contribute to the development or revision of a standard. }\end{array}$ & Participation \\
\hline 5.4 .4 & $\begin{array}{l}\text { The standard-setting organisation shall: a) identify stakeholder groups that are } \\
\text { not adequately represented; and b) proactively seek their contributions. This } \\
\text { shall include addressing constraints faced by disadvantaged stakeholders. }\end{array}$ & $\begin{array}{l}\text { Representation } \\
\text { Inclusiveness }\end{array}$ \\
\hline 5.4 .6 & $\begin{array}{l}\text { The standard-setting organisation shall make original comments received during } \\
\text { a consultation period publicly available. (aspirational good practice) }\end{array}$ & Transparency \\
\hline 5.6 .1 & $\begin{array}{l}\text { Participation in governance bodies making decisions on the content of the } \\
\text { standard shall: a) be open to all stakeholders; and b) shall be constituted by a } \\
\text { reasonable balance of those stakeholders, including those that are directly } \\
\text { affected. }\end{array}$ & $\begin{array}{l}\text { Representation } \\
\text { Inclusiveness }\end{array}$ \\
\hline 5.6 .3 & $\begin{array}{l}\text { The standard-setting organisation shall: a) strive for consensus on decisions on } \\
\text { the content of the standard; b) define criteria in advance to determine when } \\
\text { alternative decision-making procedures should come into effect, in the event } \\
\text { that consensus cannot be achieved; and c) define what the decision-making } \\
\text { thresholds will be. Those thresholds shall ensure that no one stakeholder group } \\
\text { or type can control decision-making. }\end{array}$ & $\begin{array}{l}\text { Deliberation } \\
\text { (Balanced) Representation } \\
\text { Transparency } \\
\text { Accountability }\end{array}$ \\
\hline
\end{tabular}

\subsection{Evolution}

In a way, the decline of democratic legitimation frames is thus a function of the maturity of the field. While first movers like the FSC needed to show how 'democratic' they were in order to be accepted as a new, but nonetheless legitimate form of global governance, their success in doing so means that private governance has, over the course of two decades, become a widely recognized 'pillar' of contemporary global governance. The implication is that existing regulators spend, relatively speaking, less effort on demonstrating their democratic quality. Moreover, new entrants to the field can be expected to also rely less on a democratic legitimation narrative and to emphasize performance and assurance instead.
In terms of new entrants, the RSPO, the RTRS, the Better Cotton Initiative $(\mathrm{BCl})$ and Bonsucro can serve as examples. With the exception of the RTRS, all are members of the ISEAL Alliance. Moreover, all four engage in the certification of agricultural goods or food commodities, thus distinguishing the initiatives from other ISEAL members like Equitable Origin that certifies gas and oil exploration and production, the Golf Environment Organization that certifies sustainable golf courses or GoodWeave that offers a label for carpets and rugs free from exploitative production.

So what role does democratic legitimation play in the more recent initiatives? Existing studies of the RSPO and RTRS suggest that democratic legitimation is relevant in the sense that the organizations identify themselves as 
'multi-stakeholder initiatives' that represent all relevant sectors in the supply chain for the respective commodity. At the same time, they show that both organizations have difficulties to become fully representative of the diversity of interests in their respective fields, thereby putting an inherent limit to the extent to which the organizations can use a democratic narrative as a basis for building their legitimacy (Schouten \& Glasbergen, 2011; Schouten, Leroy, \& Glasbergen, 2012). As a result, they seek to demonstrate their strength elsewhere, notably in the claim that the volumes of certification rise fast and steady. Moreover, since public contestation of the RSPO mainly revolves around the credibility of the environmental claims of certificate-holders, the organization also emphasizes credibility issues in its external communication (Nikoloyuk, Burns, \& de Man, 2010, pp. 68-69).

Again, in particular the performance claim is one that all standard systems make, so the difference is primarily in the emphasis placed on either performance or procedures. Informing about the representative nature of the initiative, the RSPO website for instance simply states that it 'unites stakeholders from the 7 sectors of the palm oil industry' and that it counts 'more than 2,500 members worldwide who represent all links along the palm oil supply chain' (RSPO, 2016). Similarly, the BCI informs that to achieve [its] mission, $\mathrm{BCl}$ works with a diverse range of stakeholders across the cotton supply chain to promote measurable and continuing improvements for the environment, farming communities and the economies of cotton-producing areas' (BCl, 2016); and Bonsucro stipulates that it 'builds a platform to accelerate change for the largest agricultural commodity in the world-sugarcane' (Bonsucro, 2016). This is different from the stronger statement of the FSC, which claims that 'to make sure no one viewpoint dominates the others, our membership has three chambers-environmental, social and economic - that have equal rights in decisionmaking' (FSC, 2016a, emphasis in the original).

A very similar picture is obtained by examining the Public System Reports (PSR) that ISEAL members are asked to update and submit annually for each of the three ISEAL Codes. Looking at the Standards Code, the FSC report is not only significantly more detailed and more comprehensive; it also puts a stronger emphasis on the organization's identity as a representative 'membership organization' (FSC, 2016b). What is relatively easy to spot, thus, is that new entrants pay less attention to democratic legitimation than the 'first movers'. The second expectation which holds that the 'first movers' themselves will reduce the role that the democratic narrative plays in their efforts to claim legitimacy over time, is more difficult to ascertain based on the PSR documents published by the ISEAL Alliance. The MSC, for instance, reports more comprehensively about the inclusiveness of its decision-making procedures than many of the more recent initiatives (MSC, 2015). This might suggest that socialization into the norms of the (early) field is stronger than expected-an idea that warrants further scrutiny.

\subsection{Expansion}

The previous section has mainly dealt with the fact that private transnational governance has become a pervasive and hence more common phenomenon in the field of natural resource governance. Yet private regulation has also expanded beyond that field, most notably so in the area of climate governance. The data Jessica Green has gathered for her book Rethinking Private Authority is particularly telling in this regard. Having collected information on 119 private environmental regulations from 1950 to 2009, Green notes that 107 of these have emerged in the 1990s and 2000s. Organizing the initiatives along 16 different sectors, she further notes that 'the carbon sector, which is the youngest at only eleven years, has the largest number of certification schemes'. It accounts for a total of 24 initiatives, 'a full 3 standard deviations above the mean' (Green, 2014, p. 96).

What this tells us is that carbon standards-which roughly fall into carbon accounting, carbon reporting and disclosure, carbon performance and carbon offsettinghave been able to build on the success of private transnational governance in the field of sustainable resources and transfer some of the basic ideas, designs and experiences to a new sector (Abbott, 2012a; Andonova, Betsill, \& Bulkeley, 2009; Dingwerth \& Green, 2015). At the same time, the initiatives we find in the carbon sector differ in two important ways. First, they include the by far smallest share of de novo regulations among all sectors17 per cent, while the share among all 119 initiatives is 53 per cent. De novo regulations, according to Green (2014, pp. 89-95), are 'entirely new' sets of rules while amended regulations 'appropriate some aspects' of existing regulations. Second, they tend to be geared towards contributing either to the broader goals set in the United Nations Framework Convention on Climate Change (UNFCCC) and the Kyoto Protocol or to specific articles of these legal agreements.

In her qualitative reconstruction of the emergence of the Greenhouse Gas (GHG) Protocol, Green (2014, pp. 132-162) demonstrates how this regulation for carbon accounting was initiated by two private actors, the World Resources Institute (WRI) and the World Business Council for Sustainable Development (WBCSD). At the same time, it was strongly nested in the regulations of the Kyoto Protocol. The latter had made the prospect of a carbon-restricted world more likely and thereby raised the demand for carbon accounting at the national, the corporate and the project level. As Green (2014, p. 161) argues, the GHG Protocol became the focal institution for carbon accounting because there was a strong demand for its services and 'because at the time there was no organization-public or private-with the expertise to fulfil the same role'. Green acknowledges that 'the transparency of the rule-making process and the willingness by WRI and WBCSD to include all interested parties endowed the process and, eventually, the rules with a high level of legitimacy' (Green, 2014, p. 162). Yet the nest- 
ing of the GHG Protocol in public intergovernmental regulation meant that legitimation itself was focused on expertise and technical know-how rather than on a democratic narrative. Private regulation did not face a need to legitimate its broader goals since these were, quite simply, meant to contribute to the goals that governments around the world had agreed upon.

A second case study of the Clean Development Mechanism (CDM) further illustrates how private transnational regulation is sometimes not as private as the label suggests and that 'delegated authority' is equally important as 'entrepreneurial authority'. In some instances, notably when an issue area is characterized by a strong focal organization, that focal organization-in the CDM case, this is the UNFCCC Secretariat-may find it useful to delegate the task of specifying standards that help to implement specific legal provisions to private actors (Green, 2008; see also Schleifer, 2013).

In sum, our comparison of transnational regulation on sustainable resource use and climate change illustrates that regulatory structure matters. Even fields that share a common issue area-environmental politicsmay thus respond to different legitimation norms. While the transnational regulation of sustainable wood, fish, palm oil or soy occurs in the absence of intergovernmental framework regulations, transnational climate regulation is strongly influenced by the UNFCCC and the Kyoto Protocol. As the goals of private regulatory initiatives resonate with internationally agreed goals, principles or instruments, the need to justify the 'right to regulate' is a different one for transnational climate governance. We can call this the state prerogative in legitimating transboundary regulation. In short, the state prerogative implies that, where (inter-)state regulation is in place, private regulation primarily legitimates itself in relation to the goals, principles and instruments of public regulation. In contrast, where (inter-)state regulation is largely absent, a 'residual' right to regulate needs to be defended. In such cases, democratic legitimation norms become central.

To some extent, this observation can also help explain why the legitimation of transnational sustainability regulation differs from the legitimation of labour rights standards. In the former, international law is weaker so that the FSC and its allies can be seen as genuine law-makers; in the latter, international human rights law serves as a strong background, and standard-setters like the Fair Wear Foundation are seen not as making, but as implementing law by way of applying it to producers. Yet, relevant contexts include not only regulatory, but also normative structures in the policy field in question. The fair trade movement, for example, does not rely much on democratic legitimation, but rather on substantive arguments about the normative adequacy of its principles even though it is not embedded in an intergovernmental regime from which it could more or less directly derive its goals or principles. So field-specific legitimation cultures are likely to play a role, too. In this context, environmental governance is sometimes considered to have a more 'participatory' culture than other areas like financial or economic governance (Bernstein, 2011, p. 42), although issue-framing as 'technical' versus 'political' may cut across this simple division. For example, governing chemical substances or the safety of nuclear power plants can be seen as environmental policy issues that, compared to conservation governance, follow a relatively strong 'technical' framing. As a result, the legitimation of industry self-regulation cases like Responsible Care or the World Association of Nuclear Operators-both under a strong shadow of state regulation-relies almost entirely on technical expertise (Braithwaite \& Drahos, 2000).

Existing research on private governance through rating agencies, accounting standards or information technology standards seems to confirm that the reliance on a strong democratic legitimation narrative is not a general, but rather a field-specific phenomenon (see e.g. Black, 2008; Botzem, 2012; Botzem \& Dobusch, 2012; Dobusch \& Quack, 2013; Kerwer, 2005). Norms of transparency and accountability also play a role in these areas, and the problem of defining stakeholder categories seems, at least occasionally, to also prompt organizations in 'technical' issue areas to justify their decisions not only in terms of expertise but also of (some variant of) the allaffected principle. But if we consider that even in the highly politicized areas of fair trade and labour standards, non-democratic criteria-notably just outcomes and respect for human rights-constitute the primary sources of legitimation, this lends support to the idea that fieldspecific cultures are central. In the end, our very rough survey thus suggests that, all else being equal, democratic legitimation narratives will be strongest where standard-setters operate in areas that are not already regulated by states, that are characterized by a 'participatory legitimation culture', and that are dominated by 'political frames'. In contrast, we should expect democratic legitimation narratives to be less central in fields where states provide a regulatory framework, where legitimation cultures are less participatory and where issues are framed mostly in 'technical' terms.

\section{Conclusion}

There are two take-home messages from this discussion. First, private transnational sustainability governance made its initial mark in global governance by successfully claiming that its decision-making procedures were based on 'democratic' or 'democracy-like' foundations-a claim that seems to have become less central as the field became more mature, more well-known, and more densely populated. This observation confirms the theoretical idea that organizational fields are dynamic and that some important lessons we may have learned about them in the past may have become outdated in the present. More precisely, private governance could initially only become legitimate if it could demonstrate its democratic credentials. But that does not necessarily mean that its democratic foundation remains as relevant in future develop- 
ment stages of the organizational field. In contrast, the argument I have presented suggests that field recognition decreased the demand for democratic legitimation.

Second, private transnational sustainability governance has expanded from its 'ecological niche' (Abbott, Green, \& Keohane, 2016) in areas in which states had long been unable to agree on substantive rules to areas in which intergovernmental rules are strong. In these areas, private transnational regulators function not as lawmakers but as implementing agencies that put international public law to work. But serving a different function also implies that the legitimation of private governance differs in these areas. This second observation essentially confirms what Edward Balleisen observes for the domestic context, namely that 'state strength' is a key variable for explaining the form private self-regulation takes as well as the legitimation norms such regulation tends to be founded upon (Balleisen, 2009). For the case I have discussed in this article, it means that the 'state prerogative' provides a second context in which the demand for democratic legitimation is reduced.

In the larger scheme of things, the normative implications of the observations I make in this article are difficult to judge. In one way, the rise of private transnational governance in the 1990s ushered in a period of 'democratic experimentalism', and the liability of newness that forced the first movers to make strong arguments about why they should be allowed to regulate 'for the rest of us' made exciting projects like the FSC and later the ISEAL Alliance possible. The institutionalization, professionalization and bureaucratization that came with the evolution of private governance into a more common and more widely recognized pillar of global governance took away some of this excitement. As a result, global democrats will need to think hard about whether private global governance is a project in which they wish to invest further hopes. In another way, however, the state prerogative could also be read as good news. It ensures that where governments-many of them democratically elected-can agree on substantive rules for which there is a strong demand, these rules are likely to guide the activities of the more experimental, more flexible and often also more innovative private regulators. This would suggest a division of labor along the lines of a 'principled pragmatism' (Ruggie, 2013; see also Abbott, 2012b) in which public regulators set the broad goals and private regulators seek diverse ways of making the achievement of these goals possible. Eventually, the 'shadow of hierarchy' (Héritier \& Lehmkuhl, 2008) that such a division of labour allows for could even become a co-benefit for resolving a further normative challenge, namely the risk of greenwashing to which critics of private transnational self-regulation frequently point.

\section{Acknowledgements}

For funding that contributed to the research I report in this paper, I am indebted to the Emmy Noether Program- me of the Deutsche Forschungsgemeinschaft (Grant No. DI1417/2-1) and to the Profile Area 'Global Democratic Governance' at the University of St. Gallen. For helpful comments on earlier versions of the manuscript, I am grateful to the participants of the workshop 'The Legitimization of Private and Public-Private Regulation: Past and Present' held at the Max Planck Institute for Legal History in Frankfurt (Main) in April 2016, to fellow participants at the 'Designing Legitimacy' workshop held at the European University Institute in Florence in June 2016, and to two anonymous reviewers. I also thank Ciarán O'Flynn for language editing.

\section{Conflict of Interests}

The author declares no conflict of interests.

\section{References}

Abbott, K. W. (2012a). The transnational regime complex for climate governance. Environment and Planning $C$ : Government and Policy, 30(4), 571-590.

Abbott, K. W. (2012b). Engaging the public and the private in global sustainability governance. International Affairs, 88(3), 543-564.

Abbott, K. W., Green, J. F., \& Keohane, R. O. (2016). Organizational ecology and institutional change in global governance. International Organization, 70(2), 247-277.

Andonova, L., Betsill, M., \& Bulkeley, H. (2009). Transnational climate governance. Global Environmental Politics, 9(2), 52-73.

Auld, G. (2014). Constructing private governance: The rise and evolution of forest, coffee and fisheries certification. New Haven, CT: Yale University Press.

Balleisen, E. J. (2009). The prospects for effective coregulation in the United States: A historian's view from the early twenty-first century. In E. J. Balleisen \& D. A. Moss (Eds.), Government and markets: Toward a new theory of regulation (pp. 443-481). Cambridge: Cambridge University Press

Bartley, T. (2007). How foundations shape social movements: The construction of an organizational field and the rise of forest certification. Social Problems, 54(3), 229-155.

Benvenisti, E., \& Downs, G. W. (2007). The empire's new clothes: Political economy and the fragmentation of international law. Stanford Law Review, 60(2), 595-631.

Bernstein, S. (2011). Legitimacy in intergovernmental and non-state global governance. Review of International Political Economy, 18(1), 17-51.

Bernstein, S., \& Cashore, B. (2007). Can non-state global governance be legitimate? An analytical framework. Regulation \& Governance, 1(4), 1-25.

Better Cotton Initiative. (2016). About BCl. Retrieved from http://bettercotton.org/about-bci

Biersteker, T. J., \& Hall, R. B. (Eds.). (2002). The emer- 
gence of private authority in global governance. Cambridge: Cambridge University Press.

Black, J. (2008). Constructing and contesting legitimacy and accountability in polycentric regulatory regimes. Regulation \& Governance, 2(2), 137-164.

Bonsucro (2016). Bonsucro-The industry platform for sugarcane. Retrieved from http://www.bonsucro.com/site

Botzem, S. (2012). The politics of accounting regulation: Organizing transnational standard setting in financial reporting. Cheltenham: Edward Elgar.

Botzem, S., \& Dobusch, L. (2012). Standardization cycles: A process perspective on the formation and diffusion of transnational standards. Organization Studies, 33(5/6), 737-762.

Braithwaite, J., \& Drahos, P. (2000). Global business regulation. Cambridge: Cambridge University Press.

Brassett, J., Richardson, B., \& Smith, W. (2012). Private experiments in global governance: Primary commodity roundtables and the politics of deliberation. International Theory, 4(3), 367-399.

Cashore, B. W., Auld, G., \& Newsom, D. (2004). Governing through markets: Forest certification and the emergence of non-state authority. New Haven, CT: Yale University Press.

Cutler A. C., Haufler, V., \& Porter, T. (Eds.). (1999). Private authority and international affairs. Albany, NY: SUNY Press.

Dingwerth, K. (2007). The new transnationalism: Transnational governance and democratic legitimacy. Basingstoke: Palgrave Macmillan.

Dingwerth, K., \& Green, J. F. (2015). Transnationalism. In K. Bäckstrand \& E. Lövgren (Eds.), The research handbook on climate governance (pp. 153-163). Cheltenham: Edward Elgar.

Dingwerth, K., \& Pattberg, P. (2006). Global governance as a perspective on world politics. Global Governance, 12(2), 185-203.

Dingwerth, K., \& Pattberg, P. (2009). World politics and organizational fields: The case of transnational sustainability governance. European Journal of International Relations, 15(4), 707-743.

Dobusch, L., \& Quack, S. (2013). Framing standards, mobilizing users: Copyright versus fair use in transnational regulation. Review of International Political Economy, 20(1), 52-88.

Forest Stewardship Council. (2016a). About us. Forest Stewardship Council. Retrieved from https:// ic.fsc.org/en/about-fsc

Forest Stewardship Council. (2016b). Standard setting in FSC (Version 1-1, submitted on 30 June 2016). Retrieved from http://www.isealalliance.org/sites/ default/files/private/FSC,\%20Standard\%20Setting\% 20Code,\%20Public\%20System\%20Report,\%20June\% 202016.pdf

Green, J. F. (2008). Delegation and accountability in the Clean Development Mechanism: The new authority of non-state actors. Journal of International Law and International Relations, 4(2), 21-55.
Green, J. F. (2014). Rethinking private authority: Agents and entrepreneurs in global environmental governance. Princeton, NJ: Princeton University Press.

Grigorescu, A. (2015). Democratic intergovernmental organizations? Normative pressures and decisionmaking rules. Cambridge: Cambridge University Press.

Gulbrandsen, L. H. (2010). Transnational environmental governance: The emergence and effects of the certification of forests and fisheries. Cheltenham: Edward Elgar.

Hannan, M. T., \& Freeman, J. (1984). Structural inertia and organizational change. American Sociological Review, 49(2), 149-164.

Haufler, V. (1993). Crossing the boundary between public and private: International regimes and non-state actors. In V. Rittberger (Ed.), Regime theory and international relations (pp. 94-111). Oxford: Clarendon.

Héritier, A., \& Lehmkuhl, D. (2008). Introduction: The shadow of hierarchy and new modes of governance. Journal of Public Policy, 28(1), 1-17.

ISEAL Alliance. (2014). Setting social and environmental standards: ISEAL Code of Good Practice (Version 6.0, December 2014). London: ISEAL Alliance.

Kerwer, D. (2005). Rules that many use: Standards and global regulation. Governance, 18(4), 611-632.

Krahmann, E. (2017). Legitimizing private actors in global governance: From performance to performativity. Politics and Governance, 5(1), 54-62.

Lipschutz, R. D., \& Fogel, C. (2002). "Regulation for the rest of us?" Global civil society and the privatization of transnational regulation. In R. B. Hall \& T. J. Biersteker (Eds.), The emergence of private authority in global governance (pp. 115-140). Cambridge: Cambridge University Press.

Marine Stewardship Council. (2015, July 1). ISEAL compliance-Standard setting code v6.0 (MSC SelfAssessment Report). Retrieved from http://www. isealalliance.org/sites/default/files/private/MSC,\%20 Standard-Setting\%20Code,\%20Public\%20System\%20 Report,\%20July\%202015.pdf

Nikoloyuk, J., Burns T. R., \& de Man, R. (2010). The promise and limitations of partnered governance: The case of sustainable palm oil. Corporate Governance: The International Journal of Business in Society, 10(1), 59-72.

Pattberg, P. (2007). Private institutions and global governance: The new politics of environmental sustainability. Cheltenham: Edward Elgar.

Rosenau, J. (1990). Turbulence in world politics. Princeton, NJ: Princeton University Press.

Rosenau, J. (1995). Governance in the twenty-first century. Global Governance, 1(1), 13-43.

Roundtable for Sustainable Palm Oil. (2016). About us. Retrieved from http://www.rspo.org/about

Ruggie, J. G. (2013). Just business: Multinational corporations and human rights. New York, NY: W. W. Norton.

Schleifer, P. (2013). Orchestrating sustainability: The case of European Union biofuel governance. Regulation \& Governance, 7(4), 533-546. 
van Dam, C. (2002). La economía de la certificación forestal: Desarrollo para quién? Paper presented at Congreso Iberoamericano de Desarrollo y Medio Ambiente 'Desafíos locales ante la globalización', Quito, Ecuador.

Van Rooy, A. (2004). The legitimacy game: Civil society, globalization and protest. Basingstoke: Palgrave Macmillan.
Wapner, P. (1995). Politics beyond the state: Environmental activism and world civic politics. World Politics, 47(3), 311-340.

Whitman, J. (Ed.). (2009). Palgrave advances in global governance. Basingstoke: Palgrave Macmillan.

Wolf, K. D. (2017). Patterns of legitimation in hybrid transnational regimes: The controversy surrounding the lex sportiva. Politics and Governance, 5(1), 63-74.

\section{About the Author}

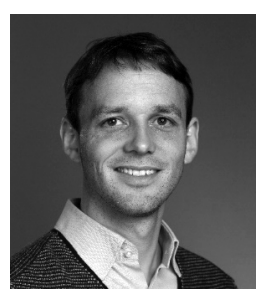

Klaus Dingwerth is assistant professor in political science at the University of St. Gallen, Switzerland. He is the author of The New Transnationalism: Transnational Governance and its Democratic Legitimacy (Palgrave Macmillan, 2007) as well as of several articles on transnational environmental governance published in the European Journal of International Relations, Global Environmental Politics and Global Governance, International Studies Quarterly. He is currently working on a book on the contested legitimation of international organizations after the Cold War. 